\title{
Mitochondrial Versus Nuclear Admixture Estimates Demonstrate a Past History of Directional Mating
}

\author{
D. ANDREW MERRIWETHER, ${ }^{2 *}$ SARA HUSTON ${ }^{2}$ SUDHA IYENGAR, ${ }^{3}$ \\ RICHARD HAMMAN ${ }^{4}$ JILL M. NORRIS ${ }^{4}$ SUSAN M. SHETTERLY, ${ }^{4}$ \\ M. ILYAS KAMBOH, ${ }^{2}$ AND ROBERT E. FERRELL ${ }^{2}$ \\ 'Department of Anthropology, University of Michigan, Ann Arbor, \\ Michigan 48109; 'Department of Human Genetics, Graduate School of \\ Public Health, University of Pittsburgh, Pittsburgh, Pennsylvania 15261; \\ ${ }^{3}$ Department of Genetics, Yale University, New Haven, Connecticut 06520; \\ ${ }^{4}$ Department of Preventative Medicine and Biometrics, University of \\ Colorado School of Medicine, Denver, Colorado 80262
}

KEYWORDS mtDNA, serological markers, admixture, Hispanics, Amerindians

\begin{abstract}
Six blood group antigens (ABO, RH, MNS, KK, KP, FY) and five plasma proteins (HP, GC, APOA4, FXIIIB, C1R) were typed in 790 individuals, and 12 mtDNA RFLP and deletion polymorphisms were typed in 657 individuals from the San Luis Valley, Colorado. The 790 nuclear typings were conducted on 399 Anglos and 391 Hispanics, while the 657 mitochondrial haplotypes were generated from 207 Anglos and 450 Hispanics. Chakraborty's ADMIX2 FORTRAN program was used to estimate the average Amerindian admixture using all nuclear loci simultaneously. Since there is no recombination in mtDNA, the sum of the frequencies of the Amerindian/Asian-specific mitochondrial haplotypes represents the level of Amerindian admixture. The nuclear estimates of Amerindian admixture were $33.15 \pm 2.41 \%$ for the Hispanics and $9.72 \pm 1.90 \%$ for the Anglos, while the strictly maternally inherited mtDNA estimates of Amerindian admixture were $85.11 \%$ for the Hispanics and $0.97 \%$ for the Anglos. This dramatic difference in estimated levels of admixture between the biparentally derived nuclear estimates and the uniparentally derived mtDNA estimates is indicative of past directional matings between Hispanic males and Amerindian females. Am J Phys Anthropol 102:153-159, 1997. 1997 Wiley-Liss, Inc.
\end{abstract}

We offer a comparison of two admixture estimates which allow us to infer the directionality of matings between two different populations living in one geographic region. The region is the San Luis Valley of southern Colorado in the counties of Alamosa and Conejos on Colorado's southern border with New Mexico. The San Luis Valley is an intermontane valley 7,100 feet above sea level. The populations of interest here are the Hispanic population, which settled the region as families on land grants in the $1700 \mathrm{~s}$, migrating north from the northern frontier of New Spain (in what is now northern New Mexico); the Anglo (non-Hispanic white) population, which entered the region in the late 1700s and early 1800s; and the existing Amerindian populations, which have inhabited the overall region of the southwest for at least 10,000 years. The study area is rural, with farming and tourism as the primary economic activities. It has been claimed (Swadesh, 1974, 1979) that "there has been little direct American Indian-Hispanic in-

*Correspondence to: D. Andrew Merriwether, Department of Anthropology, University of Michigan, 1054 LSA Building, Ann Arbor, MI 48109

Received 25 June 1996; Accepted 3 August 1996. 
termarriage" since the time of settlement in the San Luis Valley (SLV). We demonstrate that at some time during the history of the contemporary Hispanic population of the SLV, there was substantial directional mating between Hispanic males and Amerindian females. We demonstrate this by a comparison of admixture estimates using biparentally derived nuclear markers and uniparental (maternal) mitochondrial DNA (mtDNA) markers.

Schurr et al. (1990) were the first to show that all Native American populations could trace their mitochondrial (maternal) origins to a set of four "founding lineages," from which all contemporary Amerindian variation has arisen. While the majority of mtDNA lineages observed in Native American populations are related to these four clusters, Merriwether et al. (1995, 1996), Merriwether and Ferrell (1996), and Bailliet et al. (1994) have presented evidence of additional "founding" lineages for the New World, and that multiple variants of each of the founding lineages entered the New World. The initial four "Founding haplogroups" (a haplogroup is a collection of related haplotypes or lineages) were labeled A, B, C, and D by Wallace and Torroni (1992).

Lineage A is defined by the gain of a Hae III restriction site at nt position 663 , lineage $\mathrm{B}$ by a 9 -bp intergenic deletion in mitochondrial region $\mathrm{V}$, lineage $\mathrm{C}$ by the loss of a Hinc II 13259 site or the gain of an Alu I site at nt 13246 , and lineage $D$ by the loss of a site an $A l u$ I site at nt 5176 . Bailliet suggested that these lineages can be subdivided into $\mathrm{A} 1$ and $\mathrm{A} 2, \mathrm{~B} 1$ and $\mathrm{B} 2, \mathrm{C} 1$ and $\mathrm{C} 2$, and D1 and D2 by the presence or absence of a Hae III site at nt 16517 , respectively. Merriwether and Ferrell (1996) defined two additional lineages that lacked all four of the A, B, C, D markers, but possessed site gains at ng 10397 (Alu I) and nt 10394 (Dde I). These two new lineages are called X6 and X7, and differ from each other by the presence or absence of the Hae III 16517 site. The Alu I 10397 and Dde I 10394 sites are also found in all of the $\mathrm{C}$ and $\mathrm{D}$ haplotypes and are part of the definition of these haplogroups. The Alu I 10397 site gain is Asian-specific, and has never been observed outside of Asian or Asian-derived populations (Chen et al.,
1995; Torroni et al., 1994a; Merriwether and Ferrell, 1996). The Hae III 663 site gain is only seen in the New World and Asia, and is quite rare in Asia (Merriwether et al., 1995; Merriwether and Ferrell, 1996; Ballinger et al., 1992; Torroni et al., 1992, 1993a, 1993b, 1994a, 1994b, 1994c; Hertzberg et al., 1989; Harihara et al., 1992; Redd et al., 1995). The 9-bp deletion found with lineage $B$ has been observed in many world populations but seems to be Asian specific in the presence of the Hae III 16517 site gain and the absence of the Hpa I 3592 site gain which defines the African version of the deletion (Chen et al., 1995; Redd et al., 1995). Thus, we have a series of mtDNA RFLPs (see Table 1), which when assembled into haplotypes, are Amerindian/Asian-specific, and can be used to estimate admixture.

Human mtDNA does not undergo recombination (Merriwether et al., 1991; Case and Wallace, 1981), and mitochondrial haplotypes are inherited intact except for changes due to point mutations, insertions, and deletions. Thus any individual will have, in effect, either a pure Amerindian haplotype or a pure Caucasian or Hispanic haplotype. Since Amerindian mtDNA variation is limited and well defined, the frequency of the Amerindian haplotypes in a population directly reflects the frequency of Amerindian maternal lineages contributing to that population.

\section{MATERIALS AND METHODS The sample}

All samples were collected as part of the San Luis Valley Diabetes Study (SLVDS), a population-based study of non-insulin-dependent diabetes mellitus (NIDDM) cases and controls in Alamosa and Conejos counties in the San Luis Valley of Colorado. The San Luis Valley population is comprised of Hispanics and non-Hispanic whites (Anglos), and is described in detail in Hamman et al. (1989). The SLVDS began in 1983 (Hanis et al., 1983) and long-term follow-up of diabetic and non-diabetic participants is ongoing. Ethnicity was self-reported for ascertainment of Hispanic or Anglo ancestry using the 1980 census definition (U.S. Department of Commerce, 1983). 
TABLE 1. Description of mtDNA haplotypes observed in the San Luis Valley diabetes study

\begin{tabular}{|c|c|c|c|c|c|c|c|c|}
\hline Haplotype & $\begin{array}{c}\text { Hae III } \\
663\end{array}$ & $\begin{array}{c}\text { 9-bp } \\
\text { deletion }\end{array}$ & $\begin{array}{c}\text { Hinc II } \\
13259\end{array}$ & $\begin{array}{l}\text { Alu } \mathbf{I} \\
5176\end{array}$ & $\begin{array}{l}\text { Dde I } \\
10394\end{array}$ & $\begin{array}{l}\text { Alu I } \\
10397\end{array}$ & $\begin{array}{c}\text { Hae III } \\
16517\end{array}$ & $\begin{array}{c}\text { Hae III } \\
16256\end{array}$ \\
\hline $\mathrm{A} 1^{*}$ & + & $\mathrm{N}$ & + & + & - & - & + & - \\
\hline $\mathrm{A} 2 *$ & + & $\mathrm{N}$ & + & + & - & - & - & - \\
\hline $\mathbf{B} 1^{*}$ & - & $\mathrm{D}$ & + & + & - & - & + & - \\
\hline B2 & - & $\mathrm{D}$ & + & + & - & - & - & - \\
\hline $\mathrm{C} 1^{*}$ & - & $\mathrm{N}$ & - & + & + & + & + & - \\
\hline $\mathrm{C} 2 *$ & - & $\mathrm{N}$ & - & + & + & + & - & - \\
\hline C3 & - & $\mathbf{N}$ & - & + & - & - & + & - \\
\hline $\mathrm{C} 4$ & - & $\mathrm{N}$ & - & + & - & - & - & - \\
\hline $\mathrm{D} 2 *$ & - & $\mathrm{N}$ & + & - & + & + & - & - \\
\hline $\mathrm{X} 1$ & - & $\mathrm{N}$ & + & + & - & - & - & - \\
\hline $\mathrm{X} 2$ & - & $\mathrm{N}$ & + & + & + & - & - & - \\
\hline X3 & - & $\mathrm{N}$ & + & + & - & - & - & + \\
\hline $\mathrm{X} 4$ & - & $\mathrm{N}$ & + & + & + & - & + & - \\
\hline $\mathrm{X} 5$ & - & $\mathrm{N}$ & + & + & - & - & + & - \\
\hline$X 6^{*}$ & - & $\mathrm{N}$ & + & + & + & + & - & - \\
\hline$X 7 *$ & - & $\mathrm{N}$ & + & + & + & + & + & - \\
\hline
\end{tabular}

The $(+)$ indicates the presence of a restriction enzyme cleavage site at the designated nucleotide and $(-)$ indicates the absence of the site "D" indicates the presence of the 9-bp deletion, "N" indicates the absence of the 9-bp deletion, * indicates an Ameridian-or Asian-specific haplotype.

\section{Nuclear DNA}

Antigen typing of the $\mathrm{ABO}, \mathrm{RH}, \mathrm{MNS}, \mathrm{KK}$, FY, and KP loci and electrophoretic typing at the haptoglobin (HP) locus are described in Ferrell et al. (1981). Protein typings for vitamin $\mathrm{D}$ binding globulin (GC), complement component $\mathrm{C} 1 \mathrm{R}$ (C1R), coagulation factor XIIIB (F XIIIB) and apolipoprotein AIV (APO A-IV) were performed as described elsewhere (Kamboh et al., 1984; Kamboh and Ferrell, 1986a, 1986b, 1987).

\section{Mitochondrial DNA}

Samples were typed for eight polymorphic RFLP sites and one deletion site resulting in 16 different haplotypes (Table 1). Six regions of the mitochondrial genome were amplified by the polymerase chain reaction (PCR, Saiki et al., 1988). PCR conditions are described in Merriwether et al. (1991, 1995). All samples were amplified using the primer sets encompassing the following regions: 8195-8317; 5099-5333; 13212-13413; 577743; 10284-10489; and 15975-00048. All primers were 20 to 27 -mer oligonucleotides which precisely match the published sequence (Anderson et al., 1981). The PCR products were digested with the appropriate restriction enzyme by standard methods. DNA fragments were visualized and photographed under UV light and sized against known size standards ( $1 \mathrm{~Kb}$ ladder).

\section{Analytical methods}

Maximum likelihood estimates of gene frequencies for the eight nuclear loci were calculated (Rao, 1970) for Hispanics and Anglos. The computer program ADMIX2 (provided by $R$. Chakraborty) was used to estimate the average Amerindian admixture. This method utilizes a least squares procedure to estimate parameters and considers data from all loci simultaneously. We used the Amerindian and Anglo (Spanish) gene frequencies published by Hanis et al. (1986) for the parental population frequencies.

Mitochondrial admixture was estimated as the proportion of the population with Amerindian specific haplotypes. These haplotypes have been described in numerous population studies (Merriwether et al., 1995; Merriwether and Ferrell 1996; Torroni et al., 1992, 1993a). Error estimates for the mtDNA haplotypes were estimated using the error formula for proportions $(p(1-p)$ / $\mathrm{N})$.

\section{RESULTS}

Table 2 displays the gene frequencies of the 11 polymorphic nuclear markers used in this study in the SLV Hispanic and Anglo (non-Hispanic white) populations, as well as the designated parental population frequencies at these loci. Table 3 displays the fre- 
TABLE 2. Gene frequencies of the 11 nuclear gene polymorphisms in the parental and hybrid populations

\begin{tabular}{|c|c|c|c|c|c|}
\hline Locus & Genotype & $\begin{array}{l}\text { Caucasian } \\
\text { (parental) }\end{array}$ & $\begin{array}{c}\text { Amerindian } \\
\text { (parental) }^{1}\end{array}$ & Anglo & Hispanic \\
\hline \multirow[t]{4}{*}{$\mathrm{ABO}$} & A1 & 0.250 & 0.100 & 0.218 & 0.176 \\
\hline & $\mathrm{A} 2$ & 0.050 & 0.000 & 0.046 & 0.014 \\
\hline & B & 0.070 & 0.000 & 0.068 & 0.038 \\
\hline & $\mathrm{O}$ & 0.630 & 0.900 & 0.668 & 0.774 \\
\hline \multirow[t]{8}{*}{$\mathrm{RH}$} & CDE & 0.010 & 0.050 & 0.000 & 0.059 \\
\hline & CDe & 0.420 & 0.440 & 0.432 & 0.361 \\
\hline & $\mathrm{cDE}$ & 0.120 & 0.260 & 0.155 & 0.257 \\
\hline & cDe & 0.040 & 0.130 & 0.039 & 0.050 \\
\hline & $\mathrm{CdE}$ & 0.000 & 0.000 & 0.017 & 0.004 \\
\hline & Cde & 0.030 & 0.080 & 0.011 & 0.004 \\
\hline & $\operatorname{cdE}$ & 0.000 & 0.040 & 0.021 & 0.007 \\
\hline & cde & 0.380 & 0.000 & 0.325 & 0.259 \\
\hline \multirow[t]{4}{*}{ MNS } & MS & 0.250 & 0.130 & 0.184 & 0.229 \\
\hline & Ms & 0.280 & 0.570 & 0.359 & 0.383 \\
\hline & NS & 0.090 & 0.110 & 0.071 & 0.060 \\
\hline & $\mathrm{Ns}$ & 0.38 & 0.190 & 0.386 & 0.328 \\
\hline \multirow[t]{2}{*}{$\mathrm{HP}$} & HP-1 & 0.440 & 0.540 & 0.410 & 0.470 \\
\hline & HP-2 & 0.560 & 0.460 & 0.590 & 0.530 \\
\hline \multirow[t]{3}{*}{$\mathrm{GC}$} & GC-1S & 0.560 & 0.410 & 0.593 & 0.531 \\
\hline & GC-1F & 0.150 & 0.440 & 0.161 & 0.304 \\
\hline & GC-2 & 0.270 & 0.140 & 0.246 & 0.165 \\
\hline DUFFY & FYA & 0.360 & 0.710 & 0.413 & 0.447 \\
\hline (FY) & FYB & 0.640 & 0.290 & 0.587 & 0.553 \\
\hline KELL & LK & 0.040 & 0.000 & 0.024 & 0.016 \\
\hline (KK) & SK & 0.960 & 1.000 & 0.976 & 0.984 \\
\hline KELL & LK & 0.010 & 0.000 & 0.004 & 0.004 \\
\hline (KP) & SK & 0.990 & 1.000 & 0.996 & 0.996 \\
\hline \multirow[t]{3}{*}{ APO A-IV } & A-IV-1 & 0.926 & 1.000 & 0.922 & 0.929 \\
\hline & A-IV-2 & 0.072 & 0.000 & 0.078 & 0.069 \\
\hline & A-IV-3 & 0.002 & 0.000 & 0.000 & 0.002 \\
\hline \multirow[t]{3}{*}{ F XIIIB } & FB-1 & 0.745 & 0.201 & 0.743 & 0.637 \\
\hline & FB-2 & 0.093 & 0.004 & 0.093 & 0.053 \\
\hline & FB-3 & 0.162 & 0.795 & 0.164 & 0.310 \\
\hline \multirow[t]{3}{*}{$\mathrm{C} 1 \mathrm{R}$} & C1R-1 & 0.891 & 0.889 & 0.892 & 0.914 \\
\hline & C1R-2 & 0.109 & 0.014 & 0.106 & 0.066 \\
\hline & C1R-5 & 0.000 & 0.097 & 0.002 & 0.020 \\
\hline
\end{tabular}

${ }^{1}$ Source: Hanis et al. (1986)

quencies of each mtDNA haplotype in the Anglo and Hispanic populations of the SLV. Table 4 displays the nuclear and mitochondrial DNA based estimates of Amerindian admixture in the SLV Hispanic and Anglo populations. Amerindian admixture, estimated from either mitochondrial or nuclear markers, is considerably higher in Hispanics than in Anglos. Among Hispanics, the mitochondrial Amerindian admixture $(85.11 \%)$ estimate is 2.5-fold higher than the nuclear $(33.15 \%)$ estimate while both the nuclear and mitochondrial estimates of Amerindian admixture are low in Anglos.

\section{DISCUSSION}

We note distinct differences between the nuclear and mitochondrial DNA based estimates of Amerindian admixture (see Table 4), and given the strict maternal inheritance
TABLE 3. mtDNA haplotype frequencies among Anglos and Hispanics

\begin{tabular}{lcc}
\hline Haplotype & $\begin{array}{c}\text { Anglos } \\
\mathrm{N}=207) \\
\%(\mathrm{n})\end{array}$ & $\begin{array}{r}\text { Hispanics } \\
(\mathrm{N}=450) \\
\%(\mathrm{n})\end{array}$ \\
\hline $\mathrm{A}^{1}$ & $0.0(0)$ & $3.8(17)$ \\
$\mathrm{A}^{1}$ & $0.5(1)$ & $27.1(122)$ \\
$\mathrm{B} 1^{1}$ & $0.5(1)$ & $34.1(154)$ \\
$\mathrm{B} 2$ & $0.5(1)$ & $2.9(13)$ \\
$\mathrm{C} 1^{1}$ & $0.0(0)$ & $4.9(22)$ \\
$\mathrm{C} 2$ & $0.0(0)$ & $11.5(52)$ \\
$\mathrm{C} 3$ & $1.9(4)$ & $0.0(0)$ \\
$\mathrm{C} 4$ & $1.0(2)$ & $0.0(0)$ \\
$\mathrm{D} 2^{1}$ & $0.0(0)$ & $0.2(1)$ \\
$\mathrm{X} 1$ & $21.7(45)$ & $8.6(39)$ \\
$\mathrm{X} 2$ & $9.2(19)$ & $0.0(0)$ \\
$\mathrm{X} 3$ & $3.4(7)$ & $0.2(1)$ \\
$\mathrm{X} 4$ & $12.6(26)$ & $1.1(5)$ \\
$\mathrm{X} 5$ & $48.8(101)$ & $4.9(22)$ \\
$\mathrm{X} 6^{1}$ & $0.0(0)$ & $0.2(1)$ \\
X7 & $0.0(0)$ & $0.2(1)$ \\
\hline
\end{tabular}

'Amerindian/Asian-specific mtDNA haplotypes. The othe 'haplotypes are not found in unadmixed native Americans. 
TABLE 4. Amerindian admixture estimates in the San Luis Valley diabetes study

\begin{tabular}{lllll}
\hline & Anglo & Sample size & Hispanic & Sample size \\
\hline Mitochondrial \% admixture & $0.9 \pm 0.68$ & $\mathrm{~N}=207$ & $85.11 \pm 1.68$ & $\mathrm{~N}=450$ \\
Nuclear \% admixture & $9.7 \pm 1.9$ & $\mathrm{~N}=398$ & $33.15 \pm 2.4$ & $\mathrm{~N}=392$ \\
\hline
\end{tabular}

of mtDNA in humans, we use this to infer a history of strong directional mating between Native American females and Hispanic males.

Table 4 shows that by nuclear DNA estimates, SLV Hispanics are $33.15 \%$ admixed $33.15 \%$ of nuclear genes examined are of Amerindian origin), while mtDNA estimates show SLV Hispanics to be $85.11 \%$ admixed. This 2.5-fold difference is quite striking, and unequivocally points to a period of directional mating between Hispanic males and Amerindian females. As only the female mtDNA is passed on to subsequent generations, all descendants of such matings will possess the maternal Amerindian haplotype. There has either been repeated Hispanic male vs. Amerindian female mating events, or the Hispanic population continued to mate within itself fairly exclusively following an initial period of directional mating with Native Americans. Historical accounts support the latter interpretation (Swadesh, 1974, 1979; Jones, 1979; Lecompte, 1979). In either case, the Hispanic population of SLV today more closely resembles an Amerindian population (from the perspective of mtDNA variation) than it does a European population. Over $85 \%$ of SLV Hispanics tested possess pure Amerindian/Asian haplotypes. In contrast, the Anglos showed less than $1 \%$ Amerindian-admixed by mitochondrial markers, but were estimated to be $9.72 \%$ admixed by nuclear markers. The difference between the two estimates probably reflects the expected bidirectional mating between the established Hispanic population and more recent Anglo immigrants into the SLV. The estimates of Amerindian admixture among Hispanics in the SLV from nuclear data are consistent with prior estimates of admixture in Hispanics of the southwestern United States (Chakraborty et al., 1986; Hanis et al., 1986).

This study illustrates the usefulness of uniparentally inherited genetic markers for confirming or revealing patterns of direc- tional mating in hybrid populations that may not be available from historical records. Given the large number of hybrid populations worldwide, such studies may be a useful adjunct to traditional methods of evaluating populations history. A combination of uniparentally (mtDNA and Y-chromsome) and biparentally (nuclear) inherited markers may be useful in examining diseases to which uniparental genes contribute either directly or through interaction with nuclear genes. Wallace (1992) and others (Cortopassi et al., 1992; Shigenaga et al., 1994) have suggested that somatic mutations in the mitochondrial genome play a significant role in the degenerative diseases of aging, and that sequences associated with particular mtDNA haplotypes may be differentially sensitive to mutation. Knowledge of the population of origin of mitochondrial genomes in hybrid populations may reveal unique insights into the distribution of "diseases of age" in populations.

\section{ACKNOWLEDGMENTS}

This work was supported by a grant from the American Diabetes Association, and partially supported by the Pittsburgh Supercomputing Center (grant RR060099), the W.M. Keck Center for Advance Training in Computational Biology at the University of Pittsburgh, Carnegie Mellon University, and the Pittsburgh Supercomputing Center (D.A.M.). The San Luis Valley Diabetes study was supported by grants DK 30747 and CRC-RR 00051.

We also extend thanks to Aubrey Watkins for assistance in typing the mtDNA markers, Partha Majumder and Mark Shriver for assistance with the nuclear estimates of admixture, and Ranajit Chakraborty for providing his ADMIX2 program, and to the staff of the SLVDS for data collection. We thank the participants in the SLVDS for their cooperation. 


\section{LITERATURE CITED}

Anderson S, Bankier AT, Barrel BG, DeBulin MHL, Coulson AR, Drouin J, Eperon IC, Nierlich DP, Roe BA, Sanger F, Schreier PH, Smith A.JH, Staden R, and Young IG (1981) Sequence and organization of the human mitochondrial genome. Nature 290:457-465.

Bailliet G, Rothhammer F, Carnes FR, Bravi CM, and Bianci NO (1994) Founder mitochondrial haplotypes in Amerindian populations. Am. J. Hum. Genet. 54:27-33.

Ballinger SW, Schurr TG, Torronni A, Gan YY, Hodge JA, Hassan K, Chen K-H, and Wallace DC (1992) Southeast Asian mitochondrial DNA analysis reveals genetic continuity of ancient Mongoloid migrations. Genetics 130:139-152.

Case JT, and Wallace DC (1981) Maternal inheritence of mitochondrial DNA polymorphisms in cultured human fibroblasts. Somat. Cell Genet. 7:103-108.

Chakraborty R, Ferrell RE, Stern MP, Haffner SM, Hazuda HP, and Rosenthal M (1986) Relationship of prevalence of Non-Insulin Dependent Diabetes mellitus to Amerindian admixture in the Mexican Americans of San Antonio, Texas. Genet. Epidemiol. 3:435-454.

Chen Y-S, Excoffier L, Santachiara-Benerecetti AS, and Wallace DC (1995) Analysis of mtDNA variation in African populations reveals the most ancient of all . human continent-specific haplogroups. Am. J. Hum. Genet. 57:133-149.

Cortopassi GA, Shibata D, Soong HW, and Arnheim N (1992) A pattern of accumulation of a somating deletion of mitochondrial DNA in aging human tissue. Proc. Natl. Acad. Sci. U.S.A. 89:7370-7374.

Ferrell RE, Chakraborty R, Gershowitz H, Laughlin WS, and Schull WJ (1981) The St. Lawrence Island Eskimos: Genetic variation and genetic distance. Am. J. Phys. Anthropol. 53:351-358.

Hamman RF, Marshall JA, Baxter J, Kahn LR, Mayer EJ, Orleans M, Murphy JR, and Lezotte DC (1989) The San Luis Valley Diabetes Study: Methods and prevalence of Non-Insulin Dependent Diabetes Mellitus (NIDDM) in a biethnic Colorado population. Am. J. Epidemiol. 129:295-311.

Hanis CL, Ferrell RE, Barton SA, Aquilar L, GarzaIbarra A, Tuloch BR, Garcia CA, and Schull WJ (1983) Diabetes among the Mexican Americans of Starr County, Texas. Am. J. Epidemiol. 118:659-672.

Hanis CL, Chakraborty R, Ferrell RE, and Schull WJ (1986) Individual admixture estimates: Disease associations and individual risk of diabetes and gallbladder disease among Mexican Americans in Starr County, Texas. Am. J. Phys. Anthropol, 70:433441.

Harihara S, Momoki H, Suutou Y, Shimizu K, and Omoto $\mathrm{K}$ (1992) Frequency of the 9-bp deletion of mitochondrial DNA among Asian populations. Hum. Biol. 64:161-166.

Hertzberg M, Mickleson KNP, Serjeantson SW, Prior JF, and Trent RJ (1989) An asian specific 9-bp deletion of mitochondrial DNA is frequently found in Polynesians. Am. J. Hum. Genet. 44:504-510.

Jones OL (1979) Spanish Settlers on the Frontier of New Spain. Norman: University of Oklahoma Press.

Kamboh MI, and Ferrell RE (1986a) Genetic studies of low-abundance human plasma proteins. II. Popula- tion genetics of coagulation factor XIIIB. Am. J. Hum. Genet. 39:817-825.

Kamboh MI, and Ferrell RE (1986b) Genetic studies of low-abundance human plasma proteins. III. Polymorphism of the C1R subcomponent of the first complement component. Am. J. Hum. Genet. 19:826-831.

Kamboh MI, and Ferrell RE (1987) Genetic studies of huma apolipoproteins. I. Polymorphism of apolipoprotein A-IV. Am. J. Hum. Genet. 41:119-127.

Kamboh MI, Ranford PR, and Kirk RL (1984) Population genetics of the vitamin D-binding protein (GC) in the Asian, Pacific area: Description of new alleles at the GC locus. Hum. Genet. 67:378-384.

Lecompte $J$ (1979) A babel-tongued multitude on the upper Arkansas, 1832-1856. In P Kutche (ed.): The Survival of Spanish American Villages. Colorado Springs: Colorado College, pp. 63-78.

Merriwether DA, and Ferrell RE (1996) The four founding lineage hypothesis: A critical re-evaluation. Mol. Phylo. Evol. 5:1-6.

Merriwether DA, Clark AG, Ballinger SW, Schurr TG, Soodyall H, Jenkins T, Sherry ST, and Wallace DC (1991) The structure of human mitochondrial DNA variation. J. Mol. Evol. 33:543-555.

Merriwether DA, Hall WW, Vahlne A, and Ferrell RE (1996) Mitochondrial DNA variation indicates Mongolia may have been the source for the founding population for the New World. Am. J. Hum. Genet. 59: 204-212.

Merriwether DA, Rothhammer F, and Ferrell RE (1995) Distribution of the four-founding lineage haplotypes in Native Americans suggests a single wave of migration for the New World. Am. J. Phys. Anthropol. 98:411-430

Rao CR (1970) Advanced statistical methods for biometric research. Darien, CT: Hafner.

Redd AJ, Takezaki N, Sherry ST, McGarvey ST, Sofro ASM, and Stoneking M (1995) Evolutionary history of the COII/tRNALys intergenic 9 base pair deletion in human mitochondrial DNAs from the Pacific. Mol. Biol. Evol. 12:604-615.

Saiki RK, Gelfand DH, Stoffel S, Scharf SJ, Higuchi R, Horn GT, Mullis KB, and Erlich HA (1988) Primerdirected enzymatic amplification of DNA with a thermostable DNA polymerase. Science 239:487-491.

Schurr TG, Ballinger SW, Gan YY, Hodge JA, Merriwether DA, Lawrence DN, Knowler WC, Weiss KM, and Wallace DC (1990) Amerindian mitochondrial DNAs have rare Asian mutations at high frequencies suggesting a limited number of founders. Am. J. Hum. Genet. 46:613-623.

Shigenaga MK, Hagen TM, and Ames BN (1994) Oxidative damage and mitochondrial decay in aging. Proc. Natl. Acad. Sci. U.S.A. 91:10771-10778.

Swadesh FL (1974) Los Primeros Pobladores: Hispanic Americans of the Ute Frontier. Notre Dame. IN: University of Notre Dame Press.

Swadesh FL (1979) Structure of Hispanic-Indian relations in New Mexico. In P Kutche (ed.): The Survival of Spanish American Villages. Colorado Springs: Colorado College, pp. 53-62.

Torroni A, Schurr TG, Yang C-C, Szathmary EJE, Williams RC, Schanfield MS, Troup GA, Knowler WC, Lawrence DN, Weiss KM, and Wallace DC (1992) Na- 
tive American mitochondrial DNA analysis indicates that the Amerind and the Nadene populations were founded by two independent migrations. Genetics 130:153-162.

Torroni A, Schurr TG, Cabell MF, Brown MD, Neel JV, Larsen M, Smith DG, Vullo CM, and Wallace DC (1993a) Asian affinities and continental radiation of the four founding native American mitochondrial DNAs. Am. J. Hum. Genet. 53:563-590.

Torroni A, Sukernik RI, Schurr TG, Starikovskaya YB, Cabell MF, Crawford MH, Comuzzie AG, and Wallace $\mathrm{DC}$ (1993b) Mitochondrial DNA variation of aboriginal Siberians reveals distinct affinities with native Americans. Am. J. Hum. Genet. 53:591-608.

Torroni A, Lott MT, Cabell MF, Chen Y-S, Lavergne L, and Wallace DC (1994a) mtDNA and the origin of caucasians: Identification of ancient caucasian-specific haplogroups, one of which is prone to a recurrent somatic duplication in the D-loop region. Am. J. Hum. Genet. 55:760-776.
Torroni A, Miller J, Moore LG, Zamudio S, Zhuang J, Droma T, and Wallace DC (1994b) Mitochondrial DNA analysis in Tibet: Implications for the origin of the Tibetan population and its adaptation to high altitude. Am. J. Phys. Anthropol. 93:189-199.

Torroni A, Chen Y-S, Semino O, Santachiara-Benerecetti AS, Scott CR, Lott MT, Winter M, and Wallace DC (1994c) mtDNA and Y-chromosome polymorphisms in four native American populations from Southern Mexico. Am. J. Hum. Genet. 54:303-318.

US Department of Commerce (1983) 1980 Census of Population, Vol. 1 General Social and Economic Characteristics of the Population No. PC80-1-C7. US Govt. Printing Office, Colorado.

Wallace DC (1992) Mitochondrial genetics: A paradigm for aging and degenerative diseases? Science 256: 628-632.

Wallace DC, and Torroni A (1992) American Indian prehistory as written in the mitochondrial DNA: A review. Hum. Biol. 64:403-416. 